\title{
Women in limnology in the Iberian Peninsula: biases, barriers and recommendations
}

\author{
María Mar Sánchez-Montoya ${ }^{1, *}$, Ada Pastor, ${ }^{2,3}$, Ibón Aristi ${ }^{4}$, Ana Isabel del Arco, María \\ Antón-Pardo ${ }^{6}$, Mireia Bartrons ${ }^{7,8}$, Celia Ruíz ${ }^{9}$, Maria Joao Feio ${ }^{10}$, Belinda Gallardo ${ }^{11}$, Eglan- \\ tine Chappuis ${ }^{12}$ and Núria Catalán ${ }^{13}$
}

${ }^{1}$ Leibniz-Institute of Freshwater Ecology and Inland Fisheries (IGB), 12587 Berlin, Germany.

${ }^{2}$ Catalan Institute for Water Research (ICRA), Emili Grahit 101, 17003 Girona, Spain.

${ }^{3}$ Departament d'Ecologia, Universitat de Barcelona, 08028 Barcelona, Catalonia, Spain.

${ }^{4}$ Faculty of Science and Technology, University of the Basque Country, 48080 Bilbao, Spain.

${ }^{5}$ Department of Animal Biology, Plant Biology and Ecology, University of Jaén, 23071 Jaén, Spain.

${ }^{6}$ University of South Bohemia in České Budějovice, Faculty of Fisheries and Protection of Waters, South Bohemian Research Centre for Aquaculture and Biodiversity of Hydrocenoses, Institute of Aquaculture, 37005 České Budějovice, Czech Republic.

${ }^{7}$ CSIC, Global Ecology Unit, CREAF-CSIC-UAB, Cerdanyola del Vallès, 08193 Barcelona, Catalonia, Spain

${ }^{8}$ CREAF, Cerdanyola del Vallès, 08193 Barcelona, Catalonia, Spain.

${ }^{9}$ Department of Enviromental Biology, National Museum of Natural Sciences, CSIC. 28006 Madrid, Spain.

${ }^{10}$ Marine and Environmental Research Centre. Department of Life Sciences, Faculty of Sciences and Technology, University of Coimbra, 3004-517 Coimbra, Portugal.

${ }^{11}$ Departmentof Biodiversity Conservation and Ecosystem Restoration, Pyrenean Institute of Ecology (IPECSIC), 50059, Zaragoza, Spain.

${ }^{12}$ Biogeodynamics and Biodiversity Group, Center for Advanced Studies of Blanes (CEAB-CSIC), 17300 Blanes, Spain.

${ }^{13}$ Limnology, Department of Ecology and Genetics, Evolutionary Biology Centre, Uppsala University, Norbyvägen 18 D, SE-752 36, Uppsala, Sweden.

* Corresponding author: marsanch@igb-berlin.de; marsanch@um.es

Received: 19/03/2015

Accepted: 04/08/2015

\begin{abstract}
Women in Limnology in the Iberian Peninsula: biases, barriers and recommendations

Gender biases in science have received increasing attention in recent years. Underrepresentation at the highest academic levels and bias in publication are some of the factors affecting women in science. In this study, we assessed the situation of women in Limnology, a specific field of natural sciences, within the geographic context of the Iberian Peninsula. We used a multi-faceted approach to diagnose the situation, and we propose guidelines to reduce gender gaps in Limnology. The database of members of the Iberian Limnological Association (AIL) was used to analyse the variability between genders at different professional stages. Data was also compiled on plenary speakers who attended conferences organized by different associations (AIL, SEFS and ASLO) to assess women's visibility. A published data set was used to identify leadership patterns in publications with respect to gender. Finally, a survey of AIL members was conducted to understand their perception of the barriers in science that result in differences between the genders. This study recognized differences at the recruitment level (more tenured positions are held by men), visibility at conferences (fewer women are invited as plenary speakers) and publication as team leaders (men have more publications as first and last authors). Survey participants recognised the scarcity of grants/funding, difficulties in balancing life and career, and the scarcity of job opportunities as the three main barriers in science, regardless of gender. Yet, women identified family-related barriers such as having children and gender biases more frequently. Overall, our study indicates that there is a general gender bias in the field of Limnology in the Iberian Peninsula; however, it is slightly lower than the reported levels in Europe and for other disciplines in Spain. Finally, we provide a list of recommendations to balance the current biases based on suggestions made by the participants of a round table held at the XVII Congress of the AIL (Santander,
\end{abstract}


July 2014). We encourage associations in natural sciences and the AIL in particular to use this study as a guideline for best practices as well as a baseline for future analysis of gender biases.

Key words: Gender biases, women in science, limnology, AIL association, Spain, Portugal.

\section{RESUMEN}

\section{Limnólogas en la Península Ibérica: diferencias, barreras y recomendaciones}

El sesgo debido al género en ciencia ha recibido una creciente atención durante los últimos años. La infrarrepresentación en los niveles académicos más elevados y las diferencias en publicaciones, son algunas de las disparidades que afectan a las mujeres en Ciencia. En este trabajo, analizamos la situación de la mujer en la limnología, un campo específico de las Ciencias Naturales, en el contexto geográfico de la Península Ibérica. Se ha utilizado un enfoque multifacético para diagnosticar la situación de la mujer y proponer recomendaciones con el fin de reducir las diferencias de género. La base de datos de los miembros de la Asociación Ibérica de Limnología (AIL) se usó para analizar la variabilidad entre géneros a lo largo de las etapas profesionales. También se recopilaron datos sobre los/as conferenciantes en las sesiones plenarias de congresos de limnología organizados por distintas asociaciones (AIL, SEFS y ASLO) como indicador de la visibilidad de las mujeres. Además, se utilizaron datos ya publicados para identificar diferencias en el patrón de publicación entre géneros. Por último, se realizó una encuesta a los miembros del AIL para conocer su percepción sobre las barreras que afectan a las diferencias de género. El presente estudio identificó que en este ámbito científico hay diferencias a nivel de contratación (más hombres tienen una posición estable), en la visibilidad en las conferencias (menos mujeres son invitadas como conferenciantes en las sesiones plenarias) y en el liderazgo en las publicaciones (los hombres tiene más publicaciones como primer y último autor). Los participantes de la encuesta reconocieron la escasez de becas/fondos, el equilibro entre la vida familiar y laboral y la escasez de oportunidades de trabajo como las tres principales barreras en Ciencia, independientemente del género. Aún así, barreras relacionadas con tener hijos y desigualdades derivadas del género fueron destacadas más frecuentemente por las mujeres. En líneas generales, nuestro estudio indica un marcado sesgo de género en el campo de la limnología en la Península Ibérica, pero éste es ligeramente menor que el existente en Europa o en otras disciplinas en España. Por último, indicamos una lista de recomendaciones basadas en las sugerencias aportadas por los participantes en una mesa redonda celebrada en el XVII Congreso del AIL (Santander, Julio 2014). Alentamos a las asociaciones en campos de las ciencias naturales y a la AIL en particular a utilizar este estudio como una guía de mejores prácticas y como base para futuros estudios sobre el sesgo de género en ciencia.

Palabras claves: Sesgo de género, mujeres en ciencia, limnología, asociación AIL, España, Portugal.

\section{INTRODUCTION}

Currently, the female presence in academia has achieved the highest rate in history, representing more than half of undergraduate enrolments in Europe (EUROSTAT, 2006). However, women leave scientific activities at a greater rate than men at all the higher stages of an academic career. This phenomena has been described as the "leaky pipeline" (Pell, 1996) and has resulted in very high levels of vertical segregation in academic jobs (Bell, 2009; Hunt, 2010). Particularly in Spain, $56 \%$ of Masters and $51 \%$ of $\mathrm{PhD}$ students in 2012 were women, but only $20 \%$ occupied the highest professional levels (Minis- terio de Economía y Competitividad, 2014). In more technological fields, inter-gender imbalances are also the norm. For example, of a total of 6860 patents in Spain during 1999-2007, only $20 \%$ of the teams included a female inventor (Mauleón \& Bordons, 2014). This discouraging scenario for women in science can also be observed in other countries. For instance, employment rates for doctorate holders are usually higher for men than for women in Germany (94\% men vs. $72 \%$ women), United States (95\% men vs. $87 \%$ women) and Australia (86\% men vs. $72 \%$ women) (European Communities, 2007). Although cultural and social factors are often credited as the main reasons for gender bias, 
certain authors note bias based on biological differences (e.g., Lawrence, 2006), which are used to develop cultural discrimination as individuals are judged by their gender instead of their merits (Barres, 2006). The reasons why women abandon the academic career are multiple, complex and reinforce each other. For example, family lifebalance issues (Herman \& Webster, 2010; Hunt, 2010; Robinson, 2011; Ceci \& Williams, 2011) and dissatisfaction with the work culture and career advancement have been argued to be related to the higher attrition rate of women (Hunt, 2010; Fouad \& Singh, 2011).

In addition, an increasing number of studies confirm a systematic bias against women in publication (Cameron et al., 2013), which affects women's scientific productivity (Sax et al., 2002; McGuire et al., 2012). Finally, and despite the fact that overt gender discrimination has been reduced in recent decades (e.g., López Sancho et $a l ., 2013)$, bias tendency against women such as lower promotion rates and lower salaries continue to persist (McGuire et al., 2012; O'Brien \& Hapgood, 2012; Pons Peregort et al., 2014) and may contribute to perpetuating the gender leaky pipeline in science (Moss-Racusin et al., 2012).

This study's objective is to analyze the current role of women and the potential gender barriers in a scientific career in limnology within the Iberian Peninsula (i.e., Spain and Portugal). We focused our research on the Iberian Association of Limnology (AIL), which is the benchmark society of limnology in this geographical region. Specifically, this work addressed four key aspects related to the role and visibility of women in the limnological community: 1) gender gaps throughout the limnologist professional career, 2) women's visibility, which is indicated by their participation as invited key-lecturers in AIL, SEFS and ASLO conferences, 3) differences in publication in peer-reviewed journals within the limnology field, and 4) gender barrier perceptions based on a survey sent to AIL members. Finally, solutions and recommendations that were compiled after a round table that was held at the XVII Congress of the Iberian Association of Limnology (Santander, July 2014), in which results of the previous sub-sections were presented, are suggested.

The combination of all these contrasting approaches should help to identify potential gender biases and barriers in the limnological field in the Iberian Peninsula and, ultimately, provide recommendations to overcome barriers in other scientific and geographical contexts.

\section{METHODS}

\section{Gender gaps along the limnological career}

To evaluate gender gaps along the academic career, data were obtained from the database of AIL members in 2012. This database was completed

Table 1. Professional categories and stages within each category defined for this study. Categorías profesionales y etapas dentro de cada una de las categorías definidas para este estudio.

\begin{tabular}{|c|c|c|c|c|c|}
\hline \multirow[t]{2}{*}{ Private } & \multicolumn{2}{|c|}{ Public administration } & & \multicolumn{2}{|l|}{ Academia } \\
\hline & & & & Universities & Research institutes \\
\hline $\begin{array}{c}\text { Senior management: } \\
\mathrm{PhD}, \mathrm{MSc}, \mathrm{BSc} \text { and } \\
\text { superior engineers }\end{array}$ & $\begin{array}{l}\text { P-A 1st class } \\
\text { Superior } \\
\text { Technician }\end{array}$ & $\begin{array}{l}\text { With PhD } \\
\text { With MSc } \\
\text { With BSc or } \\
\text { Engineering }\end{array}$ & TENURED & $\begin{array}{l}\text { Chair } \\
\text { Full professor } \\
\text { Tenured (1) }\end{array}$ & $\begin{array}{l}\text { Research professor } \\
\text { Research scientist }\end{array}$ \\
\hline $\begin{array}{c}\text { Management: } \\
\text { Technical engineers } \\
\text { and BSc }\end{array}$ & $\begin{array}{c}\text { P-B 2nd Class } \\
\text { superior } \\
\text { technician }\end{array}$ & $\begin{array}{c}\text { Technical } \\
\text { engineers, BSc }\end{array}$ & $\begin{array}{c}\text { NON- } \\
\text { TENURED }\end{array}$ & $\begin{array}{l}\text { Long-term post-doc (2) } \\
\text { Short-term post-doc (3) } \\
\text { PhD student } \\
\text { Master } \\
\text { Technician }\end{array}$ & $\begin{array}{l}\text { Junior scientist and long-term postdoc } \\
\text { Short-grants postdoc researcher } \\
\text { PhD student } \\
\text { Master students } \\
\text { Technician }\end{array}$ \\
\hline
\end{tabular}

(1) Tenured corresponds to "Contratado doctor", "Agregado" and "auxiliar".

(2) Corresponds to: Ayudante doctor, Ramon y Cajal and contracted post-doc researchers.

(3) Corresponds to: Adjunto, colaborador, ayudante and asociado and short-grants post-doctoral researchers. 
by searching the specific position of the members in their host-institution websites when this information was lacking in the database. The professional groups and categories were defined to capture the reality of the studied countries (Spain and Portugal) and fitted to well-established international categories to allow comparisons with other studies (Table 1). First, researchers were classified depending on the sector they belong to: $1^{\text {st }}$ ) private sector, $2^{\text {nd }}$ ) public administration (except academia) and $3^{\text {rd }}$ ) academia (universities and research institutes). For private sector and public administration, two subcategories were defined based on the highest study grade achieved according to the governments' work categories. Academia is far more complex due to the high number of non-tenured figures which currently exist in the scientific Spanish and Portuguese systems. Despite the fact that the European legislation solely recognizes the grades of "chair", "full professor" and "tenured", figures such as associate professors and assistants continue to persist because of budget constraints. To integrate this complexity, in this study eight categories were used (see Table 1).

The database was also used to evaluate the "glass ceiling effect", which refers to the artificial barriers that prevent women and minorities from advancing in their careers, regardless of their qualifications and achievements (Federal Glass Ceiling Commission, 1995) and hampers women from achieving high levels of responsibility and income (Cotter et al., 2001). There are several means to evaluate the glass ceiling effect. For the purpose of this study, the procedure employed by the Comisión de Mujeres y Ciencia (2013) was used, which defines the glass ceiling as the ratio of the percentage of women in the highest category of the academic career (i.e., chair) to the percentage of women in the lowest category (i.e., technician). The index ranges from zero to infinity; a value of 1 indicates no differences between women and men in the highest category, and a greater value indicates the existence of a glass ceiling. Thus, the higher the value, the thicker the glass ceiling that impedes women's advancement to the top positions.

\section{Women's visibility: the case of invited speakers at conference meetings}

Women's participation as invited speakers at biannual AIL conferences was used to assess women's visibility from 2006 to 2014 (because previous information was not sufficiently accurate). It must be noted that the presence of four women was confirmed at the 1983, 1989, 1991 and 2002 conferences with one plenary speaker included in each. Moreover, women's participation in two other important limnology conferences within a similar time period was evaluated: the Symposium for European Freshwater Sciences (SEFS; from 2007 to 2015) and the Association for the Sciences of Limnology and Oceanography (ASLO; from 2005 to 2015).

\section{Gender analysis in Iberian limnology publications}

To investigate gender biases in publications, the database developed by Obrador \& Bonada (2014) was used. Briefly, data were obtained from the Thompson Reuters ISI Web of Knowledge (WoK) in January 2010, using different keywords related to Iberian Limnology. The search included filters by the authors' affiliation (Spain and Portugal); in addition, the time span was limited from 2000 to 2009 . For this study, solely the authors in the first and last position of the papers were considered, including papers with a single author. In cases in which the gender could not be determined (e.g., the complete name was not available, or there were unisex names), publications were removed from the database. The final database included 2602 papers (initially 2778). Within this database, the percentage of publications with one author written by women and men was calculated. In addition, for publications with two or more authors, the percentage of women and men as the first and/or last author was calculated from 2000 to 2009 to analyze temporal trends. Finally, to estimate the role of women in large collaborative projects, information from publications with ten or more authors was further analyzed. 


\section{Survey: barriers in science}

To understand whether men and women in limnology have different perceptions regarding major barriers in their career, an online survey was adapted with modifications for the Iberian Peninsula context from that conducted by L'Oréal for Cell Associates in the United States in 2010. A total of 29 questions were included in the survey; these were related to four different aspects: barriers in science, barriers in the scientific career, diversity in the workplace and personal details. All AIL members listed in the 2012 database were invited to anonymously respond to the survey. Prospective participants included $\mathrm{PhD}$ students, postdoctoral researchers, professors, technicians and unemployed fellows. The survey, available in Spanish, Portuguese and English, was launched on 15th March 2014 via an e-mail burst and closed two months later.

\section{Round table}

Results of the previous sub-sections were presented at the XVII Congress of the Iberian Association of Limnology (Santander, July 2014), and a round table was held to share experiences and suggest solutions with the audience. The following six invited researchers to the round table represented a breadth of expertise from a variety of perspectives including different nationalities

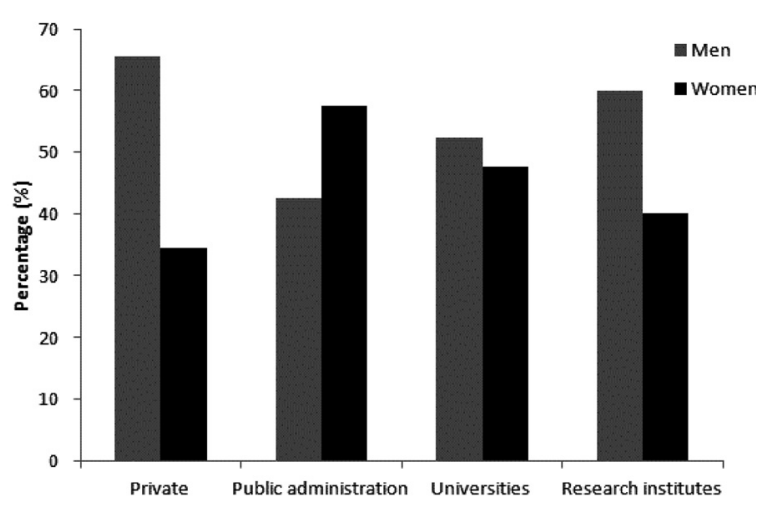

Figure 1. Percentage of men and women among the AIL members in the four work categories described in table 1. Porcentaje de hombres y mujeres entre los miembros del AIL en las cuatro categorías laborales descritas en la Tabla 1.
(Spain and Portugal), genders (male and female), and career stage (early postdoc, senior postdoc, early professor and senior professor): Isis Sanpera (University of Barcelona, $\mathrm{PhD}$ awarded in 2014), Eglantine Chappuis (CEAB-CSIC, PhD awarded in 2011), Maria J. Feio (IMAR Coimbra, $\mathrm{PhD}$ awarded in 2005), Manuel A. S. Graça (University of Coimbra, PhD awarded in 1990), Maria Rosario Vidal-Abarca (University of Murcia, $\mathrm{PhD}$ awarded in 1985) and Julia Toja (University of Sevilla, PhD awarded in 1976). The round table participants were invited to introduce themselves, comment on the results of the "Barriers in Science" survey, and propose actions to tackle gender bias within AIL. The discussion was finally opened to the public, to allow other AIL members to express their opinion and offer suggestions for improvement.

\section{RESULTS AND DISCUSSION}

\section{Gender gaps along the limnological career}

The AIL members in $2012(n=470)$ were 55\% men and $45 \%$ women. The proportion of women has increased by $10 \%$ since the AIL constitution in 1982 (65\% men, $35 \%$ women), and is currently similar to the EU-27 average of women working in knowledge-intensive activities (44\%). Moreover, the AIL female proportion is also higher than the European average of women researchers (33\% EU-27; European Commission, 2012).

AIL members worked primarily in academic institutions (78\%), including both universities (70\%) and research centres (8\%). With the exception of public administration, the presence of women was lower than men (Fig. 1). Professional leaky pipelines were consistently found in both private and academic sectors, which showed a greater proportion of women in the early stages of their professional careers followed by a shift to a male majority (Fig. 2). When comparing the gender proportion of tenured and non-tenured members $(n=348$; Fig. 2$)$, the former were primarily men $(58.5 \%)$, and non-tenured members were primarily women $(57.4 \%)$. The percentage of women in the highest categories of academic 


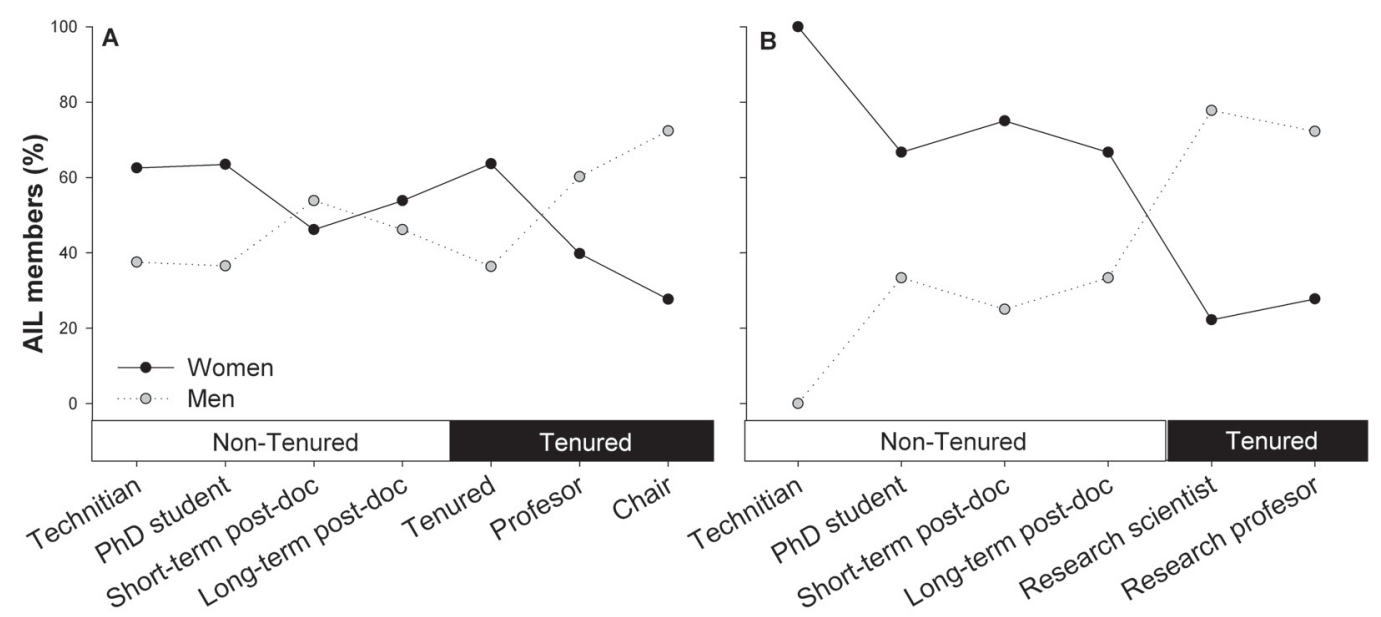

Figure 2. Proportion of women (black circles) and men (grey circles) at the different stages of the professional academic career in A) universities and B) research centres. Stages that correspond to non-tenured and tenured positions are indicated. Proporción de mujeres (círculos negros) y hombres (círculos grises) a lo largo de las diferentes etapas de la carrera académica en A) universidades B) centros de investigación. Se indican las que corresponden a posiciones permanentes y no permanentes.

institutions (i.e., chair and professors) is of $33 \%$ (Fig. 2).

Although far from equitable, this situation is better than that for the entire Spanish scientific community, in which $19.5 \%$ of women achieved the highest categories (data from Spanish Science Ministry in 2012). Moreover, only 23\% of women become full or research professors in the field of science and engineering in Europe (European Commission, 2012).

In accordance with these trends, we found a glass ceiling index in Iberian limnology of 1.77 , which is slightly lower than that reported for scientific disciplines in Spain in 2013 (1.87; Ministerio de Economía y Competitividad, 2014) and in the EU-27 in 2010 (1.80; European Commission, 2012). This result indicates that a general gender bias in the field of limnology in the Iberian Peninsula exists, although the situation of AIL female members is slightly better than that of the general Spanish and European scenarios.

\section{Women visibility: the case of invited speakers at conference meetings}

It was not until 2010 that female speakers began to regularly be invited to AIL conferences (Fig. 3). Despite the increasing trend from 2010 to

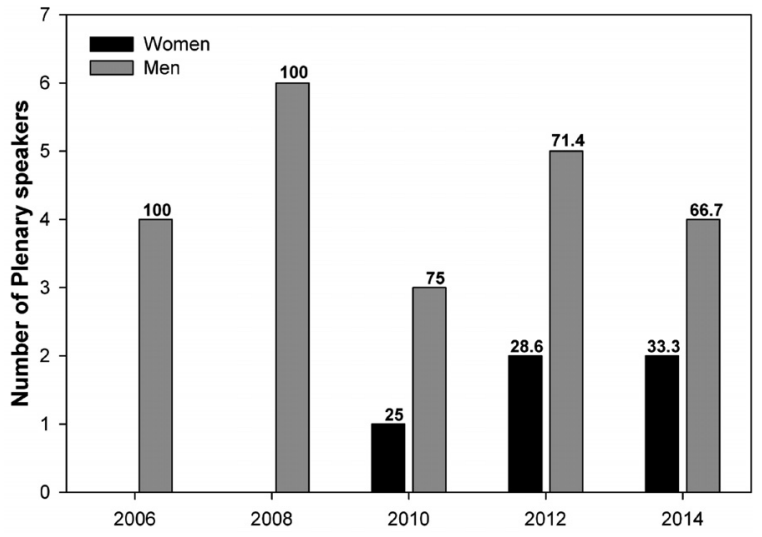

Figure 3. Number of invited plenary speakers to the AIL conferences from 2006 to 2014. Percentage of each gender is indicated above the columns. Número de conferenciantes invitados/as a las plenarias de los congresos AIL del año 2006 al 2014. El porcentaje de cada género se indica encima de las columnas.

2014 , the proportion of women as invited speakers to plenary sessions has not achieved $50 \%$ in any conference. For SEFS conferences, $50 \%$ of plenary speakers were women in 2007; however, no women were invited as plenary speakers in 2009. Proportions have been balancing since then, with $50 \%$ and $42 \%$ of women in recent editions (2013 and 2015, respectively). Regarding ASLO conferences, men dominate $(>60 \%)$ in all editions from 2005 to 2015 (with the ex- 


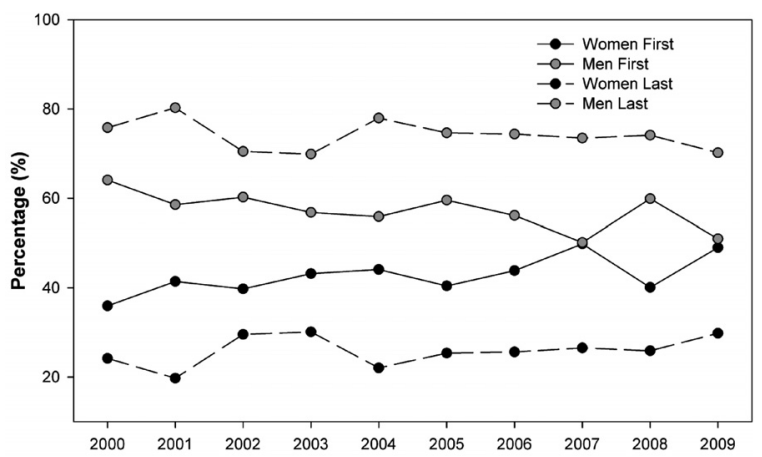

Figure 4. Proportion of publications (\%) authored in the first (solid line) and the last positions (dashed line) by women (black circles) and men (grey circles) during the study period (from 2000 to 2009). Proporción de publicaciones (\%) con el primer (línea continua) y el último autor (línea discontinua) correspondiente a mujeres (círculos negros) y hombres (círculos grises) durante el período analizado (de 2000 a 2009).

ception of 2011 in Puerto Rico, in which $80 \%$ of plenary speakers were women). To our knowledge, none of these limnological associations have included specific policies regarding the gender of the invited speakers to plenary sessions in their conference organizing guidelines. In any case, the inclusion of a gender policy may help guarantee female visibility in plenary sessions.

\section{Gender analysis in Iberian limnology publications}

The total number of papers in the final database was 2602, after removing 176 papers because the gender could not be determined. Eighty-eight of these publications were authored by a unique author: $37.5 \%$ women and $62.5 \%$ men. Regarding papers with two or more authors $(n=2514)$, women were the first and last author in $43.5 \%$ and $26.2 \%$ of cases, respectively. Temporal patterns indicate that dissimilarities have decreased during the studied period, from a minimum percentage of women of $35.9 \%$ as the first authors in $2000(35.9 \%)$ to a maximum of $49.9 \%$ in 2007 (Fig. 4). In the case of the last position in the publications, values ranged from $19.7 \%$ in 2001 to $30.1 \%$ in 2003 , which persists with no significant temporal trends (Fig. 4). For publications with ten or more authors $(n=81)$, the proportion of women as the first author decreased (17.3\%), whereas the percentage of women in the last po- sition of the author list remained similar (24.7\%).

These results are in agreement with other studies that show a gender gap in scientific publications (Symonds et al., 2006; McGuire et al., 2012; Larivière et al., 2013). However, these differences were minor for Iberian limnology compared with other studies in the field of ecology. For example, the publications exclusively authored by men in the journal Ecology were much higher than those authored solely by women $(94.6 \%$ and $5.4 \%$, respectively; Martin, 2012). The same study noted that women represented $33 \%$ of the first authors and $21 \%$ of the last authors in the journal Ecology. These numbers are likely to be related to the gender bias in the research positions; the first authors typically represent the work leader, whereas the head of the laboratory or the principal investigator often occupies the last position (Martin, 2012). Although an increase in women's productivity has reduced the gender gap in publications in the last decade (Sax et al., 2002; West et al., 2013), no clear patterns were found in this study, since the role of women as project leader, assessed by a position of last author, represented $25 \%$, regardless of the number of authors or the studied year.

\section{Survey: barriers in science}

A total of 115 of 470 members of AIL participated in the survey. Over half $(55 \%)$ of the survey respondents were women, whereas the remaining 45\% were men. Most respondents lived in Spain or Portugal (over 82\%) and worked in academic settings (67\% men, $70 \%$ women). The most common positions for women were $\mathrm{PhD}$ $(30 \%)$, followed by researchers with a stable position (24\%) and postdoctoral researchers (19\%). Men respondents were predominantly post-docs $(35 \%)$, followed by researchers with a stable position $(23 \%)$, and $\mathrm{PhD}$-students (14\%). Women participants were generally younger than men and their median age was 30 to 34 years, whereas men had a median age of 35 to 39 years. The majority of the survey's participants had less than 20 years of professional experience, and women had less professional experience than their male 
Table 2. Percentage of men and women participants in the survey who detected barriers in three categories (faced by individuals, considered significant or personally encountered). The numbers in parenthesis represent the rank for the top five. Porcentaje de hombres y mujeres participantes en la encuesta que detectaron barreras en tres categorías (las que existen, las que consideran significativas, y las que encontraron personalmente). El número en paréntesis indica la posición de las cinco barreras más importantes.

\begin{tabular}{|c|c|c|c|c|c|c|}
\hline & \multicolumn{2}{|c|}{ Barriers faced by individuals } & \multicolumn{2}{|c|}{ Most significant barriers } & \multicolumn{2}{|c|}{ Barriers personally encountered } \\
\hline & Men & Women & Men & Women & Men & Women \\
\hline Grants/Funding & $88.2(1)$ & $96.8(1)$ & $66.7(1)$ & $79.4(1)$ & $68.6(1)$ & $77.8(1)$ \\
\hline Balancing life and career & $72.5(2)$ & $81.0(2)$ & $47.1(3)$ & $55.6(2)$ & $49.0(3)$ & $54.0(3)$ \\
\hline Child support & $52.9(3)$ & 54.0 & 3.9 & $6.3(5)$ & $9.8(5)$ & 15.9 \\
\hline Gender biases & $19.6(5)$ & 31.7 & 3.9 & $12.7(4)$ & 2.0 & 12.7 \\
\hline Access to mentor & 9.8 & 14.3 & 3.9 & 1.6 & 7.8 & 11.1 \\
\hline Having children & $37.3(4)$ & $60.3(4)$ & $9.8(5)$ & $25.4(3)$ & $15.7(4)$ & $28.6(5)$ \\
\hline Elder care & $19.6(5)$ & 27.0 & 0.0 & 1.6 & 5.9 & 7.9 \\
\hline Scarcity of job & $72.5(2)$ & $63.5(3)$ & $64.7(2)$ & $55.6(2)$ & $54.9(2)$ & $58.7(2)$ \\
\hline Low pay & $52.9(3)$ & $55.6(5)$ & $35.3(4)$ & $25.4(3)$ & $49.0(3)$ & $36.5(4)$ \\
\hline
\end{tabular}

counterparts $(<10$ years: $37 \%$ men, $46 \%$ women; 10-20 years: $41 \%$ men, $30 \%$ women).

The scarcity of grants/funding, balancing life and career and the scarcity of job opportunities were the main barriers in science identified by both women and men (Table 2). It should be noted that the percentage of women that considered gender biases and family-life barriers such as having children and elder care important or significant were double than that of the men's.

When asked what resources were the most helpful in overcoming those barriers, both female and male participants cited personal friends or family (74\% men, $79 \%$ women), and colleagues or peers (46\% men, $56 \%$ women), with no major differences between genders. Survey participants cited grants/fellowships (62\% men, $59 \%$ women), corporate support (51\% men, $55 \%$ women), professional societies ( $42 \%$ men, $32 \%$ women) and tutors (29\% men, $32 \%$ women) as the four resources that they would like to have had more support from to overcome these barriers.

The vast majority of men $(88 \%)$ and women $(97 \%)$ know of colleagues who have dropped science because of the noted barriers and lack of support, and a majority recognised that colleagues who have dropped science were both men and women. The respondents cited that the three primary barriers that caused male and female colleagues to leave science were the scarcity of job opportunities, the scarcity of grants/funding, and the low pay. Interestingly, men found gender

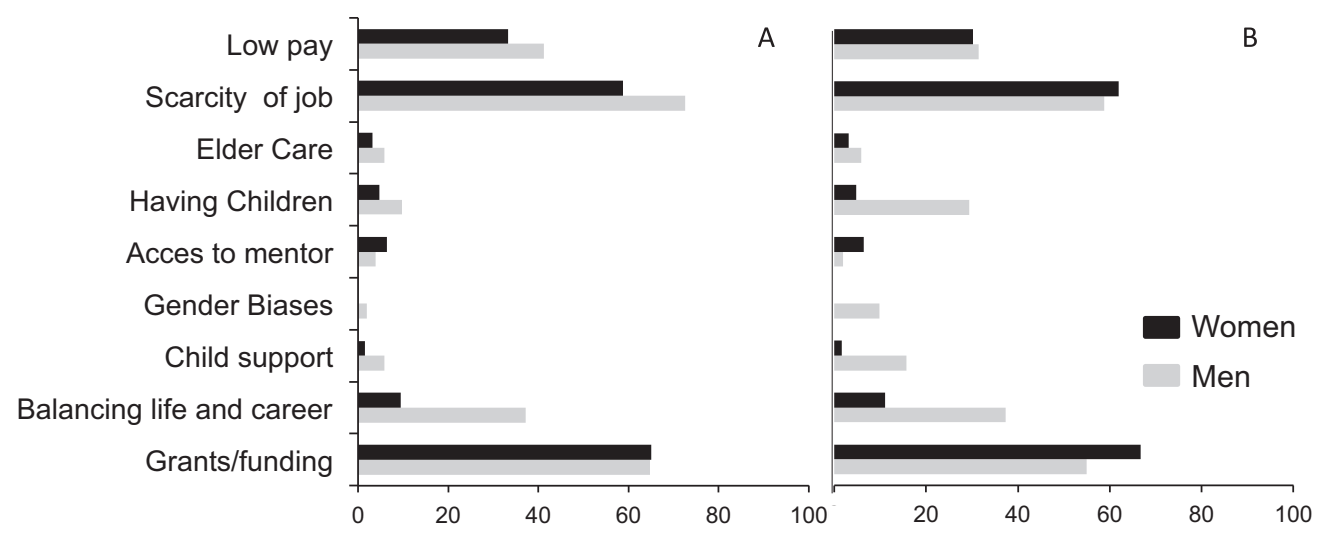

Figure 5. Percentage of men and women participants in the survey who indicated the barriers that caused their A) male colleagues and B) females colleagues to leave the science field. Porcentaje de hombres y mujeres participantes en la encuesta que indicaron las barreras que causaron que sus A) compañeros y B) compañeras de trabajo abandonaran la ciencia. 
biases, having children and child support as more relevant barriers for a woman than women respondents did (Fig. 5). In turn, women considered family related barriers as important for both genders; in addition, women indicated that female scientists generally do not decide to depart science due to gender biases.

Over half of men $(56 \%)$ and women $(51 \%)$ would not recommend pursuing a career in sciences for any gender. Additionally, a majority of the respondents $(65 \%)$ indicated that they had sacrificed personal goals to achieve their professional goals. However, men felt they have sacrificed more often $(74 \%)$ than women (57\%), and the majority of survey participants felt that both the government (87\% men, $85 \%$ women) and private corporations (79\% men, $95 \%$ women) should play a more prominent role in breaking barriers for female scientists. Finally, the majority of men and women respondents (78\% men, 67\% women) considered that their laboratories or work groups have gender diversity and that the percentage of women in their work group is between 40 and $60 \%$.

When these responses were compared to those obtained from a similar survey of 1301 men and women who held doctoral degrees in the USA in 2010 (L'Oréal by Cell Associates), many similarities were found. For instance, in both surveys, participants identified the same three primary barriers (scarcity of grants/funding, balancing life and career, and scarcity of job opportunities). Family related barriers such as having children and gender biases were identified more frequently by women in both surveys. Such coincidence is not surprising taking into account that work family balance issues have been identified by many authors as one of the main reasons for the higher drop-out rate of women from scientific careers (e.g., Herman \& Webster, 2010; Robinson, 2011). This unequal perception of women and men regarding family issues in both the USA and the Iberian Peninsula could indicate that women continue to perform the majority of the childcare and housework, and this can contribute to the observed higher rates of drop-out levels and women's lower productivity (McGuire et $a l ., 2012)$. However, it must be noted that other reasons not included in these surveys, such as women dissatisfied with the pay and promotion opportunities, could be primary drivers, since family-related constraints have been identified as a secondary factor in the field of engineering in the USA (Hunt, 2012).

\section{Round table}

Participants in the round table agreed on important advancements in decreasing gender discrimination in recent decades, although they also identified the need for improvement to achieve gender equality. A contrasting situation was detected between Spain and Portugal, because Portuguese participants agreed that they did not feel any particular gender discrimination in science, whereas Spanish participants provided several examples of discrimination. The current high female representation in Portuguese universities has been attributed to historical and political legacies, such as male graduates departing to fight in colonial wars or low salary and prestige in academic positions during Portugal's dictatorship, together with a strong feminist movement (Tavares, 2000).

Participants also highlighted the need to transform concepts from the collective memory such as women being the "caretaker" in family and society. Furthermore, the convenience of positive discrimination was discussed: most participants supported positive discrimination to achieve parity, whereas others suggested that the removal of the negative discrimination alone would be sufficient.

Solutions suggested by the audience to improve gender equality in the sciences included: a) increasing the presence of women with active roles in management boards, b) developing mentoring networks to support career development, c) increasing the number of plenary talks provided by women at conferences to achieve parity, d) reconciling work and family life by promoting flexible schedules and more child-care facilities, and e) creating social awareness, moving the discussion from academia to society. Such demands are frequent in national and international reports (Ministerio de Ciencia e Innovación, 2011). Regarding proposals that could be effectively imple- 
mented by the AIL board, the audience proposed to: a) ensure equal representation of male and female researchers in commissions, grants and overall plenary speakers (which has been occurring in recent meetings), b) increase support for parents who attend national conferences/events by organizing child-care and/or parallel activities for children, c) provide a double-blind review of manuscripts for publication in Limnetica (Journal published by the AIL), and d) follow up on gender balance within the association.

\section{CONCLUSIONS AND PERSPECTIVES}

- Our study indicates that there is a general gender bias in the field of Limnology in the Iberian Peninsula; however, it is slightly lower than the reported levels in Europe and in other disciplines in Spain, as indicated by the obtained value of the glass ceiling index.

- Important differences were recognized at the recruitment level (more tenured positions are held by men) and in publications as team leaders (more publications have male team leaders, particularly those from large projects). Although far from equitable, the gender gap in the career pathway of Iberian limnologists is smaller than the gender gap for the entirety of scientific disciplines both in Spain and in $\mathrm{Eu}-$ rope.

- The scarcity of grants/funding, balancing life and career, and the scarcity of job opportunities have been highlighted as the main barriers in science by both female and male members; yet, women identified family-related barriers such as having children and gender biases more frequently as hampering their professional development.

In summary, the results found in this study reveal Iberian Limnology as a scientific context where gender bias is important yet lower than in other scientific disciplines. Although this finding highlights the potential influence of the AIL to correct gender inequities, it is also true that temporal trends do not appear to reflect any closing of the gender gap over time. We believe that the AIL can have a proactive role in reducing inequalities, by ensuring equal representation in management boards, committees and grants, guaranteeing a chance at publication in its journal Limnetica, and by boosting the career/family balance of its members by supporting the participation of parents in scientific meetings. Additionally, through initiatives such as Young-AIL, the association should continue to represent a platform of debate of gender issues in the limnological community, with the potential to become a reference group for other scientific disciplines and societies. These actions are feasible within the means of the association and would contribute to increase the welfare of its members. Therefore, we encourage AIL to use this study as a guideline for best practices as well as a baseline for future evaluation of gender balance within the association.

\section{ACKNOWLEDGEMENTS}

First, we want to thank Antonio Camacho, president of the Iberian Association of Limnology, for supporting this study. We acknowledge $\mathrm{N}$. Bonada and B. Obrador for the database of publications. In addition, we are very grateful to all the AIL members who participated in the survey of barriers and science, and the invited speakers and assistants to the round table at the XVII Congress of the Iberian Association of Limnology (Santander, July 2014), who greatly contributed to the discussion and search for solutions. We thank two anonymous reviewers that help to improve this manuscript. M. M. SánchezMontoya was supported with the MC-Intra European Fellowship (CLITEMP Project-330466), M. Bartrons with the European Research Council Synergy grant (ERC-2013-SyG 610028IMBALANCE-P), B. Gallardo with a Severo Ochoa Program for Centres of Excellence in R+D+I (SEV-2012-0262), E. Chappuis with an Intramural CSIC project (ref. 0065) and N. Catalán with a studentship from the Wenner-Gren foundation (Sweden). 


\section{REFERENCES}

BARRES, B. A. 2006. Does gender matter? Science, 442: 133-136.

BELL, S. 2009. Women in science: maximising productivity, diversity and innovation. Canberra: Federation of Australian Scientific \& Technological Societies (FASTS).

CAMERON, E. Z., M. E. GRAY \& A. M. WHITE. 2013. Is publication rate an equal opportunity metric? Trends in Ecology and Evolution, 28: 7-8.

CECI, S. J. \& W. M. Williams. 2011. Understanding Current Causes of Women's Underrepresentation in Science. Proceedings of the National Academy of Sciences, 108: doi:10.1073/pnas.1103900108.

COMISIÓN DE MUJERES Y CIENCIA. 2013. Comisión Mujeres y Ciencia. Informe Mujeres Investigadoras CSIC 2013.

COTTER, D. A., J. M. HERMSES, S. OVADIA \& R. VANNEMAN. 2001. The glass ceiling effect. Social Forces, 80: 655-681.

EUROSTAT. 2006. http://epp.eurostat.ec.europa.eu/ portal/page/portal/science_technology_innovation/ data/database

EUROPEAN COMMUNITIES. 2007. Statistic in focus. Science and technology. 131/2007. Author Tomas Meri. ISSN 1977-0316. Catalogue number: KS-SF-07-131-EN-C.

EUROPEAN COMMISSION. 2012. She Figures 2012. Gender in research and innovation. Statistics and Indicators.

FEDERAL GLASS CELING COMMISSION. 1995. Solid investment: making full use of the Nation's Human Capital. Washington, D.C, EEUU.

FOUAD, N. \& R. SINGH. 2011. Stemming the Tide: Why Women Leave Engineering. Executive Summary. University of Wisconsin; Milwaukee.

HERMAN, C. \& J. WEBSTER. 2010. Taking a lifecycle approach: redefining women returners to science, engineering and technology. International Journal of Gender, Science and Technology, 2: 127.

HUNT, J. 2010. Why do women leave science and engineering? NBER Working Paper 15853, National Bureau of Economic Research, MA, USA.

HUNT, J. 2012. Why do women leave science and engineering? Discussion Paper Series, Forschungsinstitut zur Zukunft der Arbeit, No. 6885.

LARIVÈRE, V., C. NI, Y. GINGRAS, B. CRONIN \& C. R. SUGIMOTO. 2013. Global gender disparities in science. Nature, 504: 211-213.
LAWRENCE, P. A. 2006. Men, Wonan and Ghosts in Science. PLoS Biology, 4: 13-15.

LÓPEZ SANCHO, P. J. ÁLVAREZ MARRÓN, F. DE PABLO, J. MASEGOSA GALLEGO, M. C. MAYORAL GASTÓN, E. MOLINA HERNÁNDEZ, E. PÉREZ SEDEÑO, F. PUERTAS MAROTO \& L. M. SANDALIO GONZÁLEZ. 2013. La Comisión de Mujeres y Ciencia del CSIC: diez años promoviendo la igualdad de oportunidades y la excelencia en el organismo. Arbor, 189(759): a012.

MARTIN, L. J. 2012. Where are the women in ecology? Frontiers in Ecology and the Environment, 10: $177-178$.

MAULEÓN, E. \& M. BORDONS. 2014. Indicadores de actividad tecnológica por género en España através del estudio de patentes europeas. Revista Española de Documentación Científica, 37. doi: http://dx.doi.org/10.3989/redc.2014.2.1093

McGUIRE, K. L., R. B. PRIMACK \& E. C. LOSOS. 2012. Dramatic Improvements and Persistent Challenges for Women Ecologists. BioScience, 62: 189-196.

MINISTERIO DE CIENCIA E INNOVACIÓN. 2011. Cambio estructural de las instituciones científicas: impulsar la excelencia, la igualdad de género y la eficiencia en la investigación y la innovación. España

MINISTERIO DE ECONOMÍA Y COMPETITIVIDAD. 2014. Científicas en cifras 2013. Estadísticas e indicadores de la (des)igualdad de género en la formación y profesión científica. España

MOSS-RACUSIN, C. A., J. F. DOVIDIO, V. L. BRESCOLL, M. J. GRAHAM \& J. HANDELSMAN. 2012. Science faculty's subtle gender biases favor male students. Proceedings of the National Academy of Sciences, 109: 16474-16479.

OBRADOR, B. \& N. BONADA. 2014. Limnological research in the Iberian Peninsula: a ten-year survey of published literature. Limnetica, 33: 175-188.

O'BRIEN, K. R. \& P. K. HAPGOOD. 2012. The academic jungle: ecosystem modelling reveals why women are driven out of research. Oikos, 121: 999-1004.

PELL, A. N. 1996. Fixing the leaky pipeline: women scientists in academia. Journal of Animal Science, 74: 2843-2848.

PONS PEREGORT, O., M. D. CALVET PUIG, M. TURA SOLVAS \& C. MUÑOZ ILLESCAS. 2014. Análisis de la Igualdad de Oportunidades de Género en la Ciencia y la Tecnología: Las carreras 
profesionales de las mujeres científicas y tecnólogas. Omnina Science IC, 2013-9(1): 65-90 h. ROBINSON, C. V. 2011. Women in science: In pursuit of female chemists. Nature, 476:273-275.

SAX, L. J., L. S. HAGEDORN, M. ARREDONDO \& F. A. DICRISI. 2002. Faculty research productivity: exploring the role of gender and family-related factors. Research Higher Education, 43: 423-446.

SYMONDS, M. R. E., N. J. GEMMELL, T. L. BRAISHER, K. L. GORRINGE \& M. A. ELGAR.
2006. Gender differences in publication output: Towards an unbiased metric of research performance. PLoS ONE, 1 (1), e127.

TAVARES, M. 2000. Movimentos de Mulheres em Portugal-décadas de 70 e 80. Lisboa: Livros Horizonte.

WEST, J. D., J. JACQUET, M. M. KING, S. J. CORREL \& C. T. BERGSTRO. 2013. The role of gender in scholarly authorship. PlosONE, 8(7): e66212. doi:10.1371/ journal.pone.0066212. 